\title{
News coverage of the 2019 Romanian presidential elections in the international media
}

\author{
Ion STAVRE ${ }^{1}$ \\ Monica ILIE-PRICA ${ }^{2}$
}

\begin{abstract}
:
This article aims to analyze the news coverage of the main political events in Romania as seen by the international media, focusing on the presidential elections. The data analysis is based on news reports from all over the world and the findings show that there is a polarization in the presentation of the candidates and the political parties in the media, an aspect which has a direct impact on Romania's country image abroad.
\end{abstract}

Keywords: elections, political campaign, liberalism, pro-Europeanism, diaspora

JEL classification: P48, F50, F59

DOI: $10.24818 /$ RMCI.2021.1.47

\section{Introduction}

In 2019, Romania was the centre of several major events, with great impact at international level, such as the Presidency of the Council of the European Union, which was marked by the informal summit of the EU leaders in Sibiu, on May 9, and the historic visit of Pope Francis. But 2019 was also the year with two important elections: the first one, in May, was dedicated to the European Parliament elections, the second one, in November, was dedicated to the presidential elections, which ended with the victory of liberal candidate and incumbent president Klaus Iohannis, thus establishing Romania's pro-European path.

After 1990, the presidential elections were the most exciting electoral tournaments, because the electoral camps are well defined, because the electorate expects spectacular verbal duels. The presidential elections in Romania look very much like a battle between gladiators, in the forum, of which only one wins, and the public, by vote, is the one who raises the finger in favour of the winner.

The election campaign has a very important stake in terms of power: the president of Romania presides over the Supreme Council of National Defence (CSAT), considered the second government of Romania, of which a part of the government ministers and heads of intelligence services. The CSAT makes foreign policy decisions, military decisions, but does not have access to the most important

\footnotetext{
${ }^{1}$ Ion Stavre, College of Communication and Public Relations, SNSPA, Bucharest, Romania, Email: ion.stavre@comunicare.ro.

${ }^{2}$ Monica Ilie-Prica, College of Communication and Public Relations, SNSPA, Bucharest, Romania, Email: monica.ilie-prica@comunicare.ro
} 
budgetary decisions, which are the responsibility of the government and parliament. This duality is confirmed by the Constitution of Romania, adopted in 1991, adapted after the French one from 1958.

Thus, Romania is a semi-presidential power. This division of power was one of the almost obsessive guidelines of the National Constituent Assembly, which drafted the new Constitution after Nicolae Ceaușescu's removal from power. The memory of the dictatorship was so overwhelming that the Constitution prevented the concentration of power in one hand. An inevitable measure for a country that had just escaped a political dictatorship of 50 years and a personal dictatorship of 24 years.

The presidential elections have another characteristic: in 2004, the ruling political party at that time, the PSD, more specifically its leader, Adrian Năstase, initiated a constitutional amendment regarding the length of the presidential term. It has been increased from 4 years (as long as a parliamentary term) to 5 years. The amendment was made, as the former leader of the PSD, prime minister at that time, was considered a favourite of the elections. The gap between the presidential elections and the parliamentary elections also had a public explanation: that of not bringing into the presidential campaign the influence of the ruling party, considered to be favoured by the fact that it is in power and organizes the elections.

The change is debatable, regarding the advantages and disadvantages for the Romanian electorate.

\section{Legal framework}

Before discussing the results of our in-depth research, we will present the legal framework for the European elections and the presidential elections.

The European Parliament elections are organized in Romania in accordance with Law no. 33/2007 on the organization and conduct of elections for the European Parliament. This law establishes some specific rules for this type of election:

- political parties that already have members in the European Parliament receive $4 / 5$ of the total broadcast time. Political parties participating for the first time in these elections receive $1 / 5$ of the total broadcast time.

The provisions of Law no. 33/2007 are supplemented at each election round by the decision of the National Audiovisual Council, which is released a month before the elections. In 2019, the CNA issued decision no. 308 of March 26, regarding the rules for the audiovisual conduct of the electoral campaign for the election of the Romanian members in the European Parliament. With this decision, the CNA establishes some important rules for all radio and video broadcasters in Romania.

First of all, the categories of programs that can be made during the electoral campaign are established: electoral promotion programs, electoral debates and electoral spots, which can not exceed 30 seconds. The presence in the radio and public television programs is free. In the case of private televisions, the appearances are for a fee. Electoral programs include recorded productions, with variable duration, which contain information about the candidate's electoral campaign. The productions and the responsibility for the content belong to the

Review of International Comparative Management

Volume 22, Issue 1, March 2021 
candidates. The Romanian law makes a distinction between the parties that already have MEPs and those who present candidates for the first time. The differentiation is made by the free broadcast time to which they have access: $4 / 5$ is allocated to the parties that already have representatives in the European Parliament and 1/5 to the parties that are candidates for the European Parliament for the first time. In 2019, for the 33 seats allocated to Romania in the European Parliament, 13 political parties and 3 independent candidates joined the electoral race.

The elections in Romania for the 2019 European Parliament brought to the polls the largest turnout, both in Romania and in the European Union. Following these elections, Romania has the second largest group in the EPP and the third in the Renew Europe group. The elections marked a setback of the Social Democratic Party, which fell under the number of MEPs that the political party previously had. The biggest surprise was the USR-PLUS alliance, which became the third national group within the Renew Europe group.

The electoral debates were focused on internal issues, and European issues were very little present. It is a general characteristic of these elections, because, first and foremost, journalists are not interested in these topics. Secondly, the internal topics are more spectacular because they can generate disputes, considered the basic ingredient for attracting the audience for these shows.

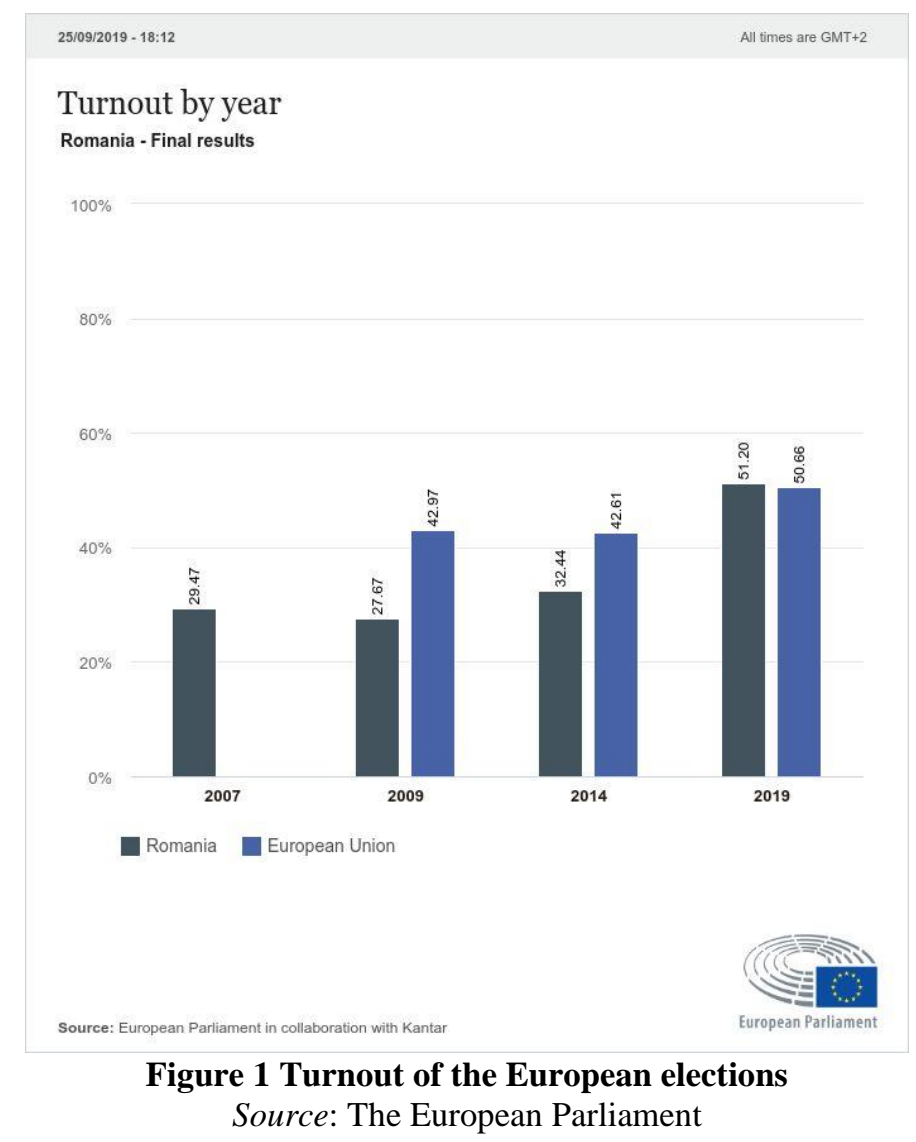

49 Review of International Comparative Management

Volume 22, Issue 1, March 2021 
The presidential elections are held according to Law 370/2004. In the sixth section of the law, starting with article 35, there are presented the general regulations regarding the way the electoral campaign is carried out in the media, with specific provisions for public radio and television. These provisions are supplemented at each presidential election by a decision of the CNA (National Audiovisual Council). The CNA decision no. 781 of September 2019 on the rules for audiovisual conduct of the election campaign for the election of the President of Romania establishes the basic rules regarding the candidates' appearances and the categories of programs that can be broadcast by radio and television.

The broadcasters were able to broadcast the following categories of shows:

- shows for electoral promotion. These are recorded shows, which contain reports, election clips, interviews during the election campaign. The basic characteristic of these shows is that they are produced by the technical teams of the candidates, according to the technical standards indicated by the speakers.

- shows for electoral debate, in which the candidates or their representatives can participate.

- informative programs, which refer to the election news.

There were 14 running in the 2019 presidential elections. Even if the election law allows the registration of the independent candidates, there are zero chances for an independent candidate, without the support of a party at national level.

The most important candidate was Klaus Iohannis, the incumbent president, credited with the greatest chances. The Prime Minister, Viorica Dăncilă, the candidate of the Social Democratic Party, was permanently considered the candidate who could, in the best case, get in the second round.

The communication strategy of the candidate Klaus Iohannis was simple: avoiding any direct debates, which used to be, up to these elections, some sort of final of the European Football Championship. The debates with journalists considered close to the party that supported Viorica Dăncilă were also avoided. This strategy was accompanied by a campaign where the competence, the ability of the candidate Dăncilă to sustain a discussion about governance was minimized.

In these conditions, the result of the elections was, to paraphrase the title of a very well-known novel by Gabriel Garcia Marquez, the chronicle of a competition with a foretold winner, Klaus Iohannis - 65.88\%, Viorica Dăncilă $-34.12 \%$.

\section{Methodology}

The research was carried out between October 10 and November 30, 2019, and it focused on the news coverage of the events related to the presidential elections in Romania in the international media. The topics that were debated by the Romanian and foreign journalists in the media were, in chronological order, the fall of the Dăncilă Cabinet, the nomination of Ludovic Orban as Prime Minister, the appointment of the Orban Cabinet, after the vote in the Parliament, the first

Review of International Comparative Management

Volume 22, Issue 1, March 2021 
round and the second round of the presidential elections. 136 news reports were analyzed, out of which 99 were exclusively related to the topics mentioned above, and the rest of 37 referred to such subjects like the confirmation of Laura Codruța Kovesi as EU chief prosecutor, the nomination of the EU Commissioner for Transport from Romania, the massive deforestation in Romania and the forestry crimes that shocked the entire world, and also the protests of the Greenpeace organization against illegal logging. Moreover, other topics debated by the foreign correspondents in the mentioned timeframe were Rudolph Giuliani's involvement in Hunter Biden's businesses with Romanian businessman Puiu Popoviciu, the European Commission's decision to continue the monitoring of the graft cases in Romania, by the Mechanism for Cooperation and Verification (CVM), and Adrian Zuckerman's appointment as US ambassador to Romania.

The research questions were:

- What was the international news coverage of the candidates for the presidential elections in Romania?

- What were the main topics in the foreign press related to Romania during the campaign for the presidential elections?

- What were the keywords associated with Romania's name in the international media?

- What was the international media's perception of Romania in the context of the presidential elections?

All the sources that were used for the content analysis were retrieved from the Internet, from press agencies, printed and online press, TV networks and radio stations, such as AFP, Reuters, Radio Free Europe, Euronews, DW, France 24, TV5Monde, RFI, BBC, CNN, Bloomberg, New York Times, Washington Post, Politico, Le Figaro, RTVE and many others, from countries like France, Germany, the USA, the UK, Spain, and Belgium.

\section{Findings}

As we can observe in Table 1 , the countries that had the top news coverage, after the news reports' frequency, were France (50), the USA (20), and Germany (17), followed by the UK (10) and Belgium (7). The data contain both the news strictly related to the Romanian presidential elections and the other subjects about Romania mentioned above. The reports were written partly by Romanian journalists who collaborate with different media, and we need to specify here that those journalists were particularly biased, and partly by foreign correspondents who are well-informed about the situation in Romania and in the Balkans, in general, and who presented the information in a neutral way, without being for or against any political parties or candidates. They rather wanted to inform properly the general public than to contribute with their article to the campaign for the presidential elections. Even so, Romania's image abroad is constantly shaped and influenced by the articles, photos and videos depicting the state of this country every day.

51 Review of International Comparative Management Volume 22, Issue 1, March 2021 
Table 1. Frequency of the news reports after the source's origin

\begin{tabular}{|c|c|}
\hline Country/Region & $\begin{array}{l}\text { Number of news } \\
\text { reports }\end{array}$ \\
\hline Argentina & 1 \\
\hline Austria & 2 \\
\hline Balkans & 2 \\
\hline Belgium & 7 \\
\hline Bulgaria & 1 \\
\hline China & 1 \\
\hline Czech Republic & 4 \\
\hline France & 50 \\
\hline Germany & 17 \\
\hline Hungary & 2 \\
\hline Hong Kong & 1 \\
\hline Ireland & 1 \\
\hline Italy & 1 \\
\hline Luxembourg & 1 \\
\hline Mexico & 1 \\
\hline Qatar & 1 \\
\hline Spain & 8 \\
\hline Switzerland & 3 \\
\hline United Kingdom & 10 \\
\hline United States & 20 \\
\hline Vatican & 1 \\
\hline Venezuela & 1 \\
\hline & 136 cases \\
\hline
\end{tabular}

The following figures represent a separate analysis of the 99 news reports specifically related to the political events during the presidential campaign and the first and second rounds of the elections. 


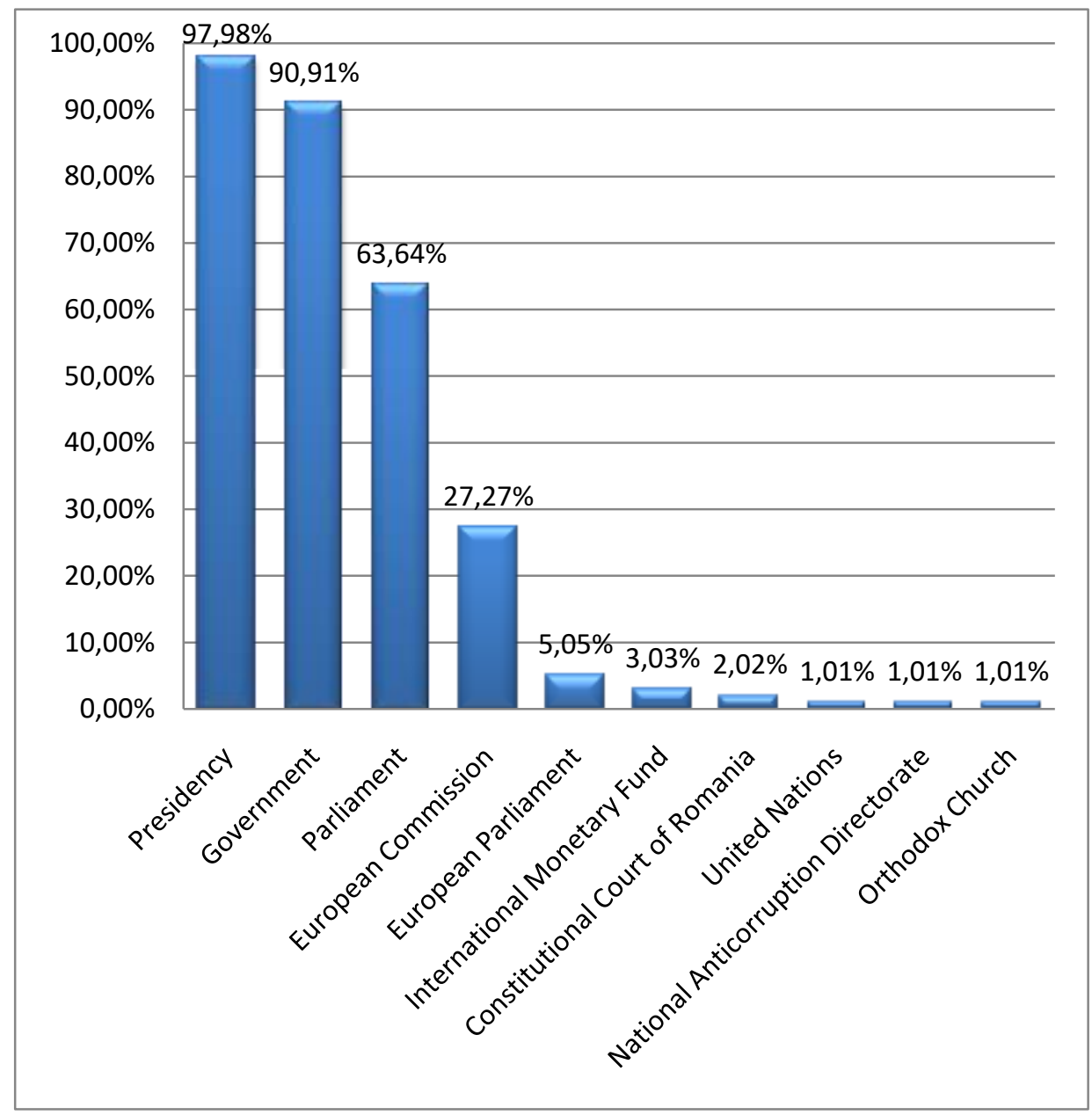

Figure 2 Percentage of foreign news reports on institutions

The results of the data analysis illustrated in Fig. 2 show that the Presidency was the main institution mentioned in the news reports, being present in almost all the articles, followed by the Government and the Parliament. This is because during the electoral campaign, the Dăncilă Cabinet was replaced by the Orban Cabinet, supported by the President and by the Parliament's vote. Moreover, Klaus Iohannis was considered an incumbent candidate for Presidency, as he was about to take office as the head of the Romanian state for the second time. The European Commission and the European Parliament were quite visible, too, in the articles about Romania, especially because there was a long debate on the Transport Commissioner from Romania for the von der Leyen Commission, as the Social Democrats nominated several candidates until Adina Vălean from the liberals' team was finally accepted. As for the most popular topics about Romania in the analyzed period (see Fig. 3), the second round of the presidential elections

53 Review of International Comparative Management

Volume 22, Issue 1, March 2021 
was the main topic, followed by the first round of the presidential elections. The international press focused on the presidential elections because most people were interested to know who would be the next head of the state, as Romania is a member of the European Union and NATO and is relevant in the international context owing to its geo-strategic importance.

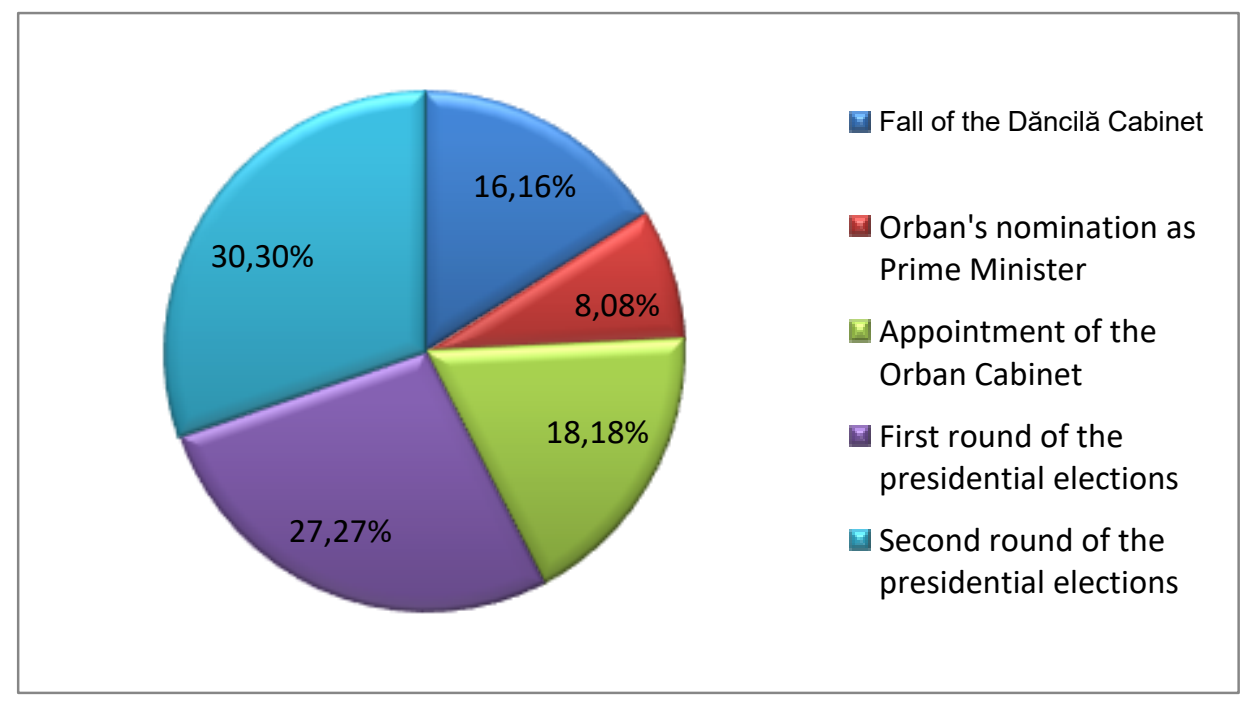

Figure 3 Percentage of foreign news topics on Romania's political events during the presidential campaign and elections

As for the candidates for Presidency mentioned in the news reports, President Klaus Iohannis and former Prime Minister Viorica Dăncilă had the highest visibility in the media, maybe also because they were the main candidates for Presidency, followed at a great distance by Dan Barna from the political party Save Romania Union (see Fig. 4). The USR is a new party in Romanian politics and it participated in only one electoral campaign, in 2016. It is necessary to specify here that the other candidates for the presidential elections had limited visibility in the international media, so they were not particularly relevant to the press. 


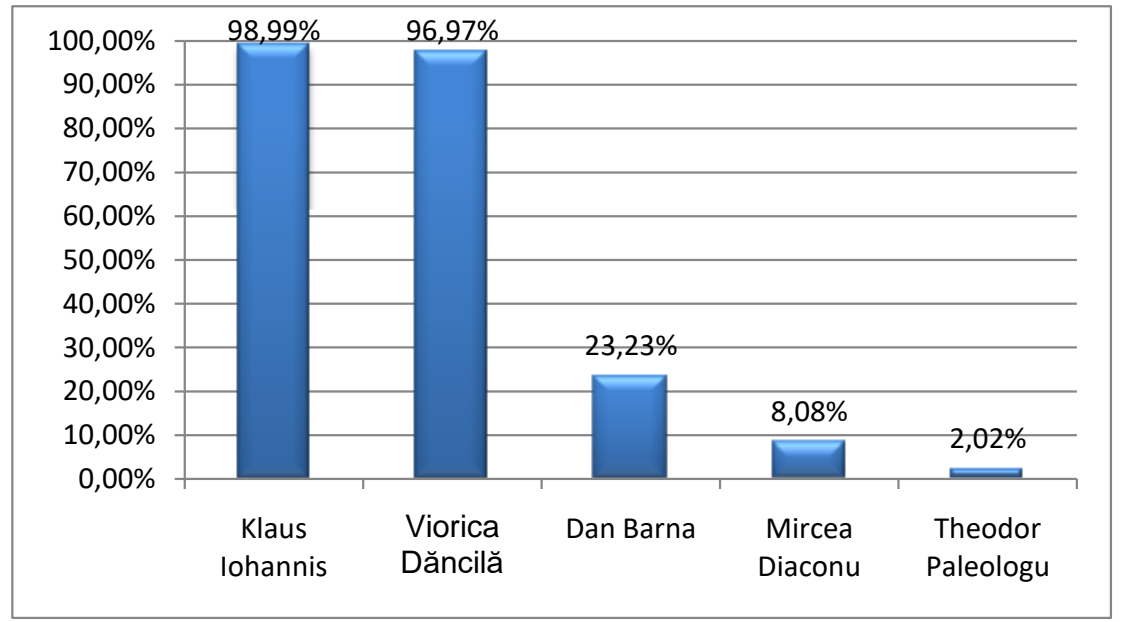

Figure 4 Percentage of mentioned candidates

The political actors with the greatest visibility in the international media were, again, Klaus Iohannis and Viorica Dăncilă, not just because of the presidential elections, but also because Dăncilă received a no-confidence vote in the Parliament. Another significant name in the news reports about Romania was the new Prime Minister and head of the PNL, Ludovic Orban, who was an active presence in the political campaign, as well, supporting the liberals' candidate for Presidency, Klaus Iohannis. At a greater distance were Liviu Dragnea, the former head of the PSD, who was prosecuted for abuse of office, and the leader of the Save Romania Union, Dan Barna, who was the third favourite candidate for Presidency (see Fig. 5).

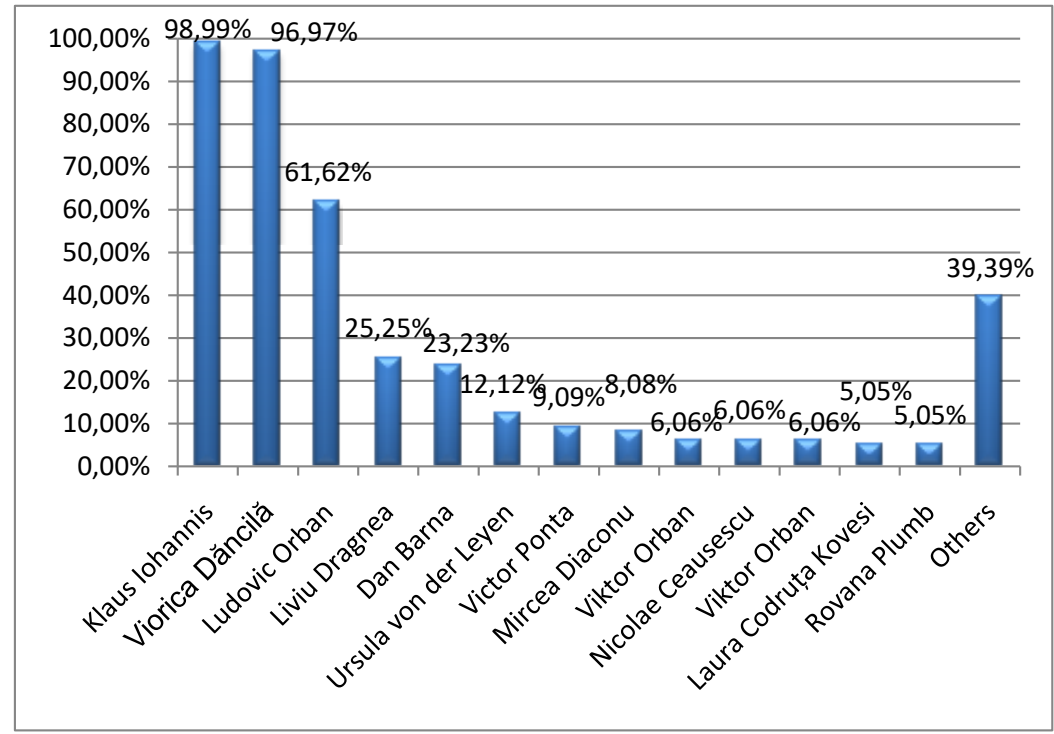

Figure 5 Percentage of mentioned political actors 
When it comes to the visibility of the political parties, the PSD and the PNL were highly discussed in the foreign press (see Fig. 6). The PSD was associated with the old Communist Party, while the PNL was considered an alternative to the communists or the socialists, and a secure way to the European future of Romania, an opportunity to get rid of the reminiscence of the communist era and to be anchored in the European Union and NATO.

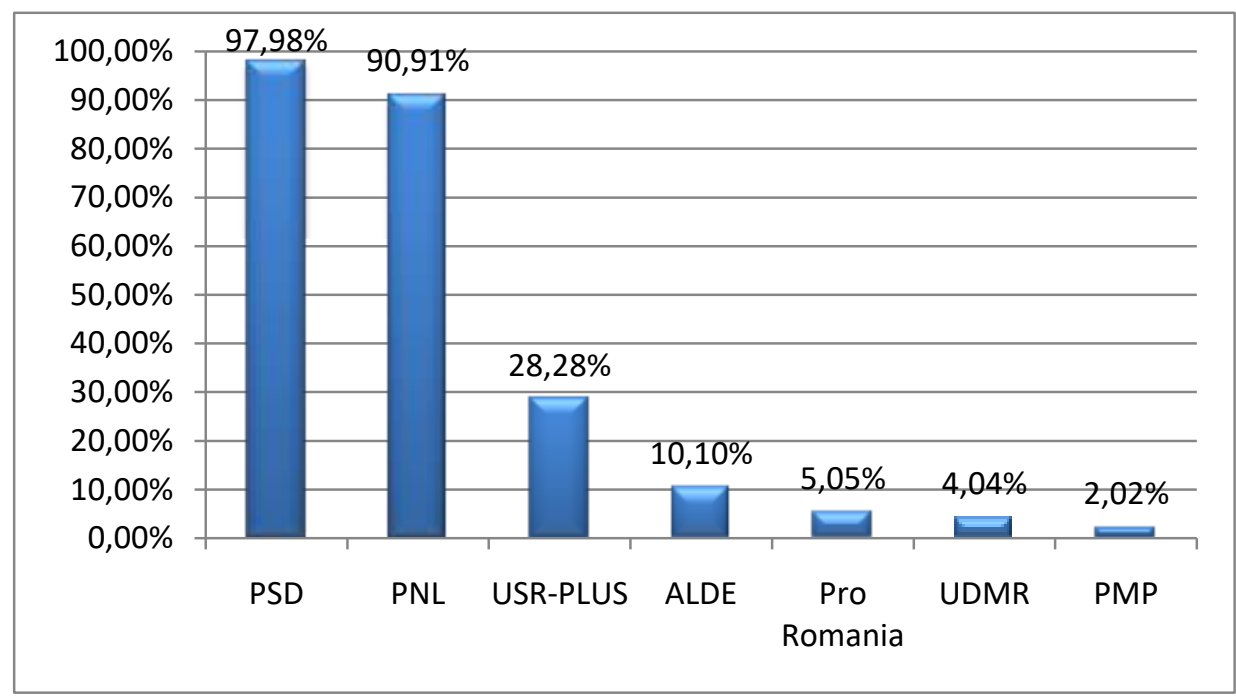

Figure 6 Percentage of mentioned political parties

In the next 6 charts (Fig. 7-Fig. 12), we observe that there is negative bias of the international media for the PSD and Viorica Dăncilă and positive bias for the PNL and Klaus Iohannis. Most articles criticized the decisions of the PSD, especially because they generated the "political turmoil", affecting the justice system and undermining the rule of law. Most articles associated the PSD with "corruption" and "the Communist Party", while the PNL was associated with "ProEuropeanism" and Iohannis was considered "the guardian of democracy". There were also neutral articles, which neither criticized, nor praised the political parties or the presidential candidates. We may also highlight here that from the 99 articles which referred exclusively to the presidential elections and the change of the government, only one had negative remarks to Iohannis, as it was a critical article to Romania, in general, and only one had positive remarks to Dăncilă, which means that the PSD and its presidential candidate had no chance to convince the international press to support them in order to have a more positive image from the foreign audiences' perspective. In addition to this aspect, the Romanian diaspora had a clear preference for the PNL and Iohannis and it was very determined to vote against the PSD and Dăncilă. 


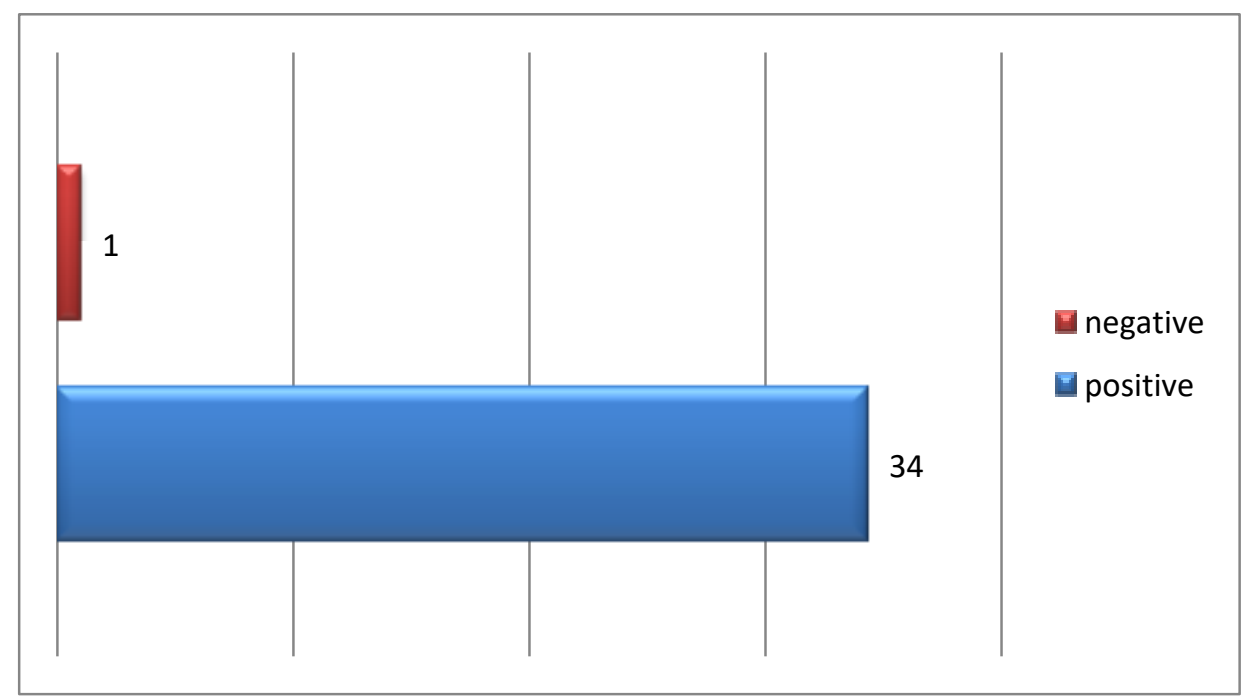

Figure 7 News coverage of Klaus Iohannis

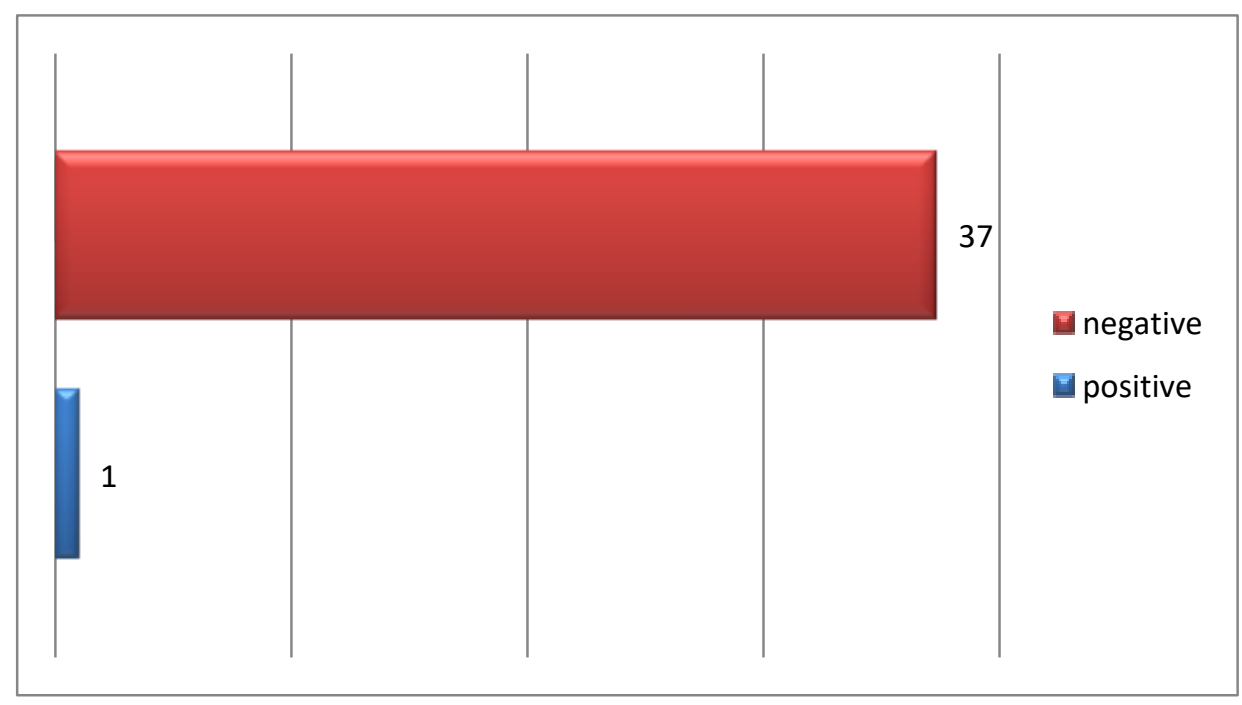

Figure 8 News coverage of Viorica Dăncilă

57 Review of International Comparative Management

Volume 22, Issue 1, March 2021 


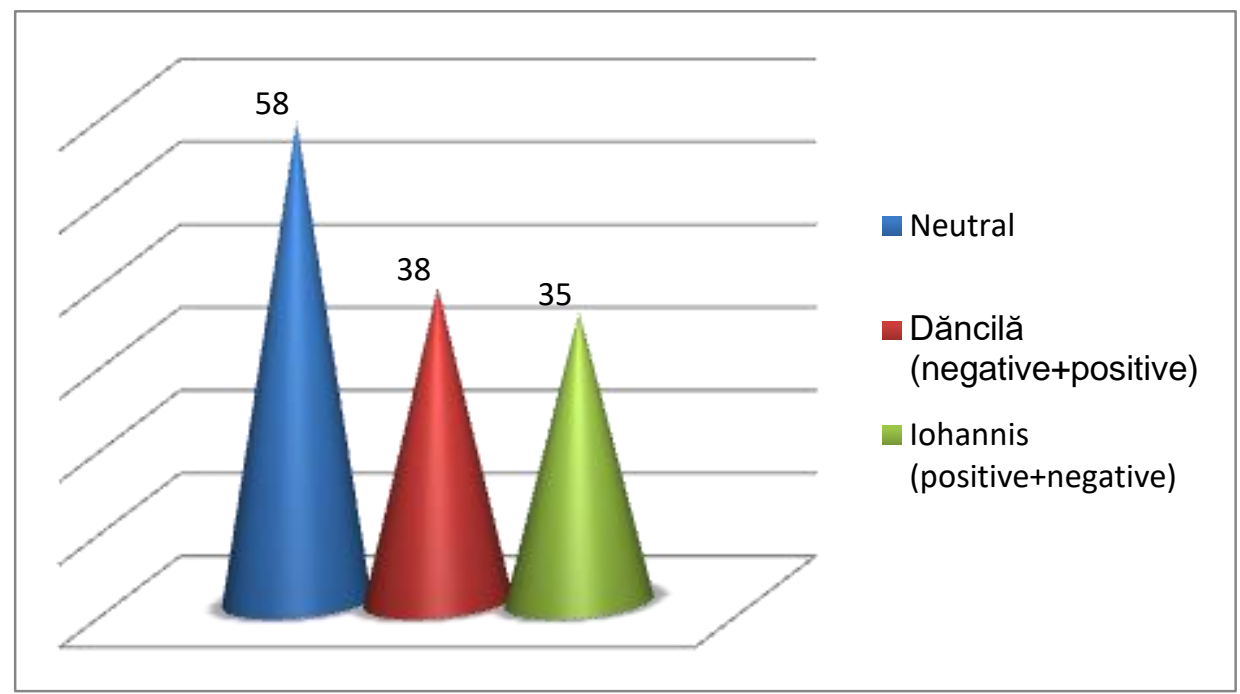

Figure 9 News coverage of Klaus Iohannis and Viorica Dăncilă (positive, negative and neutral)

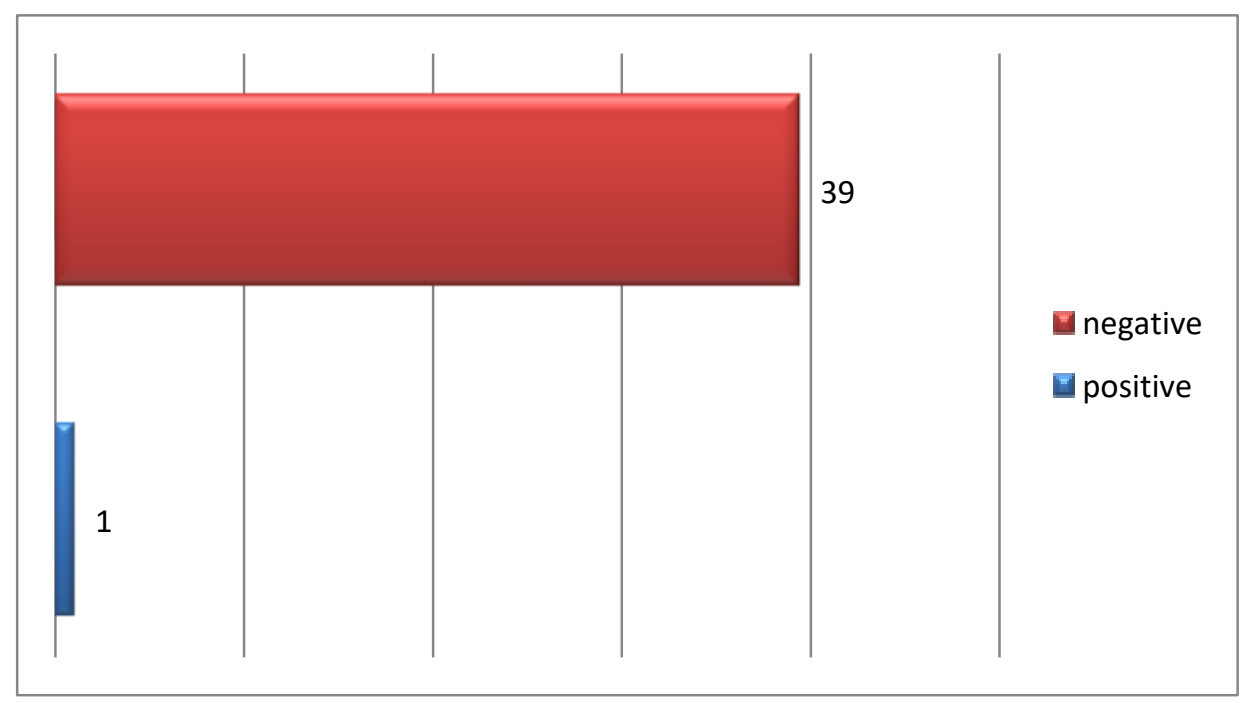

Figure 10 News coverage of the PSD 


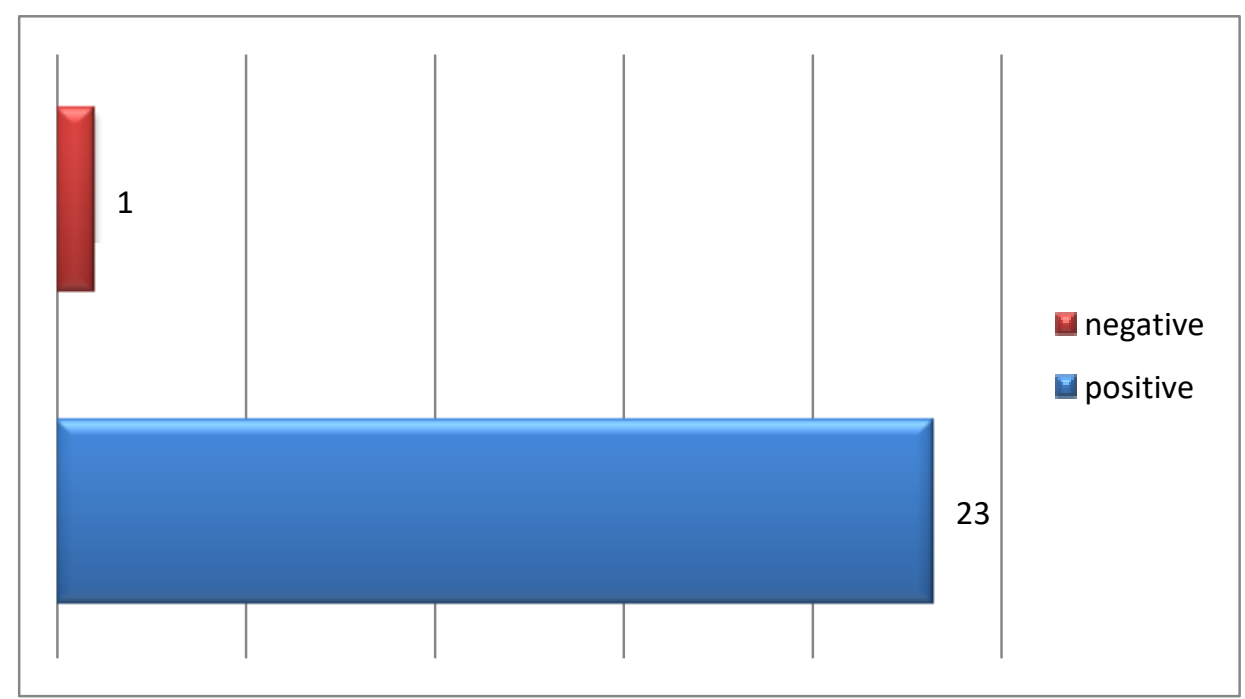

Figure 11 News coverage of the PNL

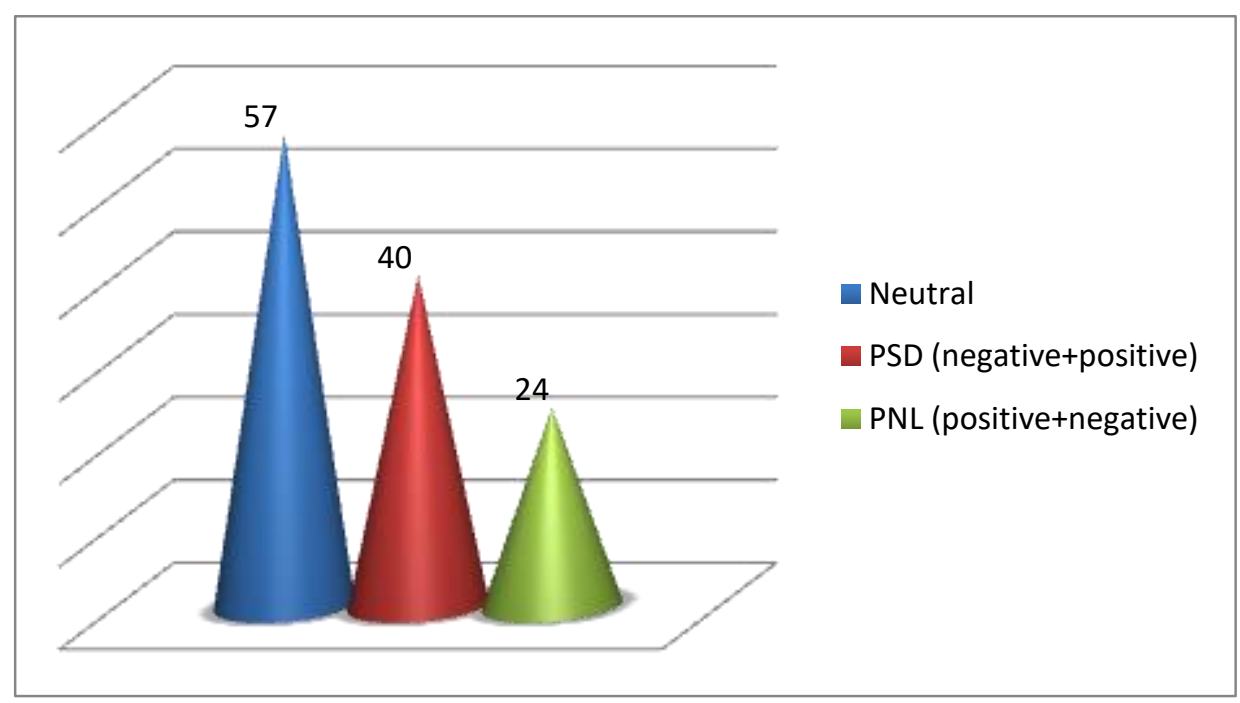

Figure 12 News coverage of the PSD and the PNL (positive, negative and neutral)

We will continue the analysis by answering the research questions. In order to answer the first question, What was the international news coverage of the candidates for the presidential elections in Romania?, we will get back to the data illustrated in the charts. As expected, the incumbent president Klaus Iohannis was a prominent presence in the international media, being mentioned in almost all the news reports from all over the world, from France to the United States, from China to Qatar. And, more than that, Iohannis benefited from a positive image throughout the entire campaign, the international media considering him "a tireless advocate of 
the European values" (TV5Monde), a teacher of Physics and "a soft-spoken ethnic German" (Reuters) who had a "meteoric rise in Romanian politics" (DW), "a clear favourite in the upcoming presidential election" and "the favourite for the presidency" (Euronews), "Romania's 'fire-fighter' president" or "the fire-fighter who prevented Romania from collapsing", "the guardian of democracy" and "an ally of President Trump" (France 24), a pro-European "in pole position" (Le Figaro), "the president who pulled Romania back from the brink" (Bloomberg), and "someone who could solve the corruption problem in Romania", as President Trump said (France 24), just to mention a few of the remarks found in the news reports, as Iohannis was also acclaimed for his "huge victory" (Euronews), "crushing his socialist challenger" (Euronews, France 24, and Epoch Times). It is also mentioned that Iohannis "sees eye-to-eye with Berlin and Paris on most issues, sometimes to the irritation of the leaders in nearby Budapest and Warsaw" and he is considered "a favourite to consolidate liberalism in Europe" (France 24). It is necessary to mention here that some critics said that Iohannis is "lacks charisma and is a poor public speaker" (France 24), and that he "lacks energy and is more reactive than proactive" (Bloomberg), but all in all such opinions were very few. So, we can observe that the foreign press had a high regard for Iohannis, but not also for the second candidate, Viorica Dăncilă, who was portrayed in a totally different way, having a negative image at international level. She and the PSD were amply criticized for their incompetence and misuse of EU funds, but also for undermining the rule of law, for expansionary fiscal policies which caused deficits in the national budget and current account. The PSD has the "communist legacy" (DW) and it is "a threat to the rule of law" (EurActiv), as there was no surprise that the European Parliament elections were "a stinging defeat for the PSD" (New York Times). At the same time, the articles' authors have mentioned repeatedly the name of Liviu Dragnea, the former leader of the socialists and the one who was considered "the most powerful politician who was put behind the bars for corruption" (Bloomberg). Another candidate who was mentioned in the media, but not as much as Iohannis and Dăncilă, was Dan Barna, the leader of the Save Romania Union. He was seen as "a little charismatic character, almost transparent, without substance" (Balcani Caucaso), and maybe because of this low profile he didn't get in the second round of the presidential elections. In fact, many thought that he would be confronting Iohannis in the second round and that Dăncilă and the PSD would be totally defeated, but in the end the USR-PLUS failed to meet the voters' expectations after the huge victory in the European elections, in May 2019.

Continuing the analysis with the second research question, What were the main topics in the foreign press related to Romania during the campaign for the presidential elections?, we can say here that the media talked extensively about the fight against corruption, about Romania's pro-European choice, but also about the judicial reforms and the rule of law. Other aspects referred to the economic growth, but also to the budget deficit caused by the PSD governments, and this could be a real problem in 2020 and later on, according to the International Monetary Fund. Aside from the political crisis in Bucharest, which ended with the collapse of the Dăncilă Cabinet, replaced by the liberals led by Prime Minister Ludovic Orban, 
and with the victory of the PNL candidate and incumbent president Iohannis in the elections, there were other important topics, like the election of Adina Vălean as European Commissioner for Transport, the appointment of Laura Codruța Kovesi as the first European chief prosecutor, and the confirmation of Adrian Zuckerman as the new US ambassador to Romania. Another discussion which was visible in the press by the end of the analyzed period referred to the early elections expected for 2020, another poignant electoral year for Romania, with local and general elections that will have a great impact on the country in the next four years.

As for the third research question, What were the keywords associated with Romania's name in the international media?, we can say that the keywords associated with Romania depended a lot on the political actors. For instance, Romania was seen as a "pro-European", "modern", "normal" country when President Iohannis was mentioned, while the references to the PSD placed Romania in a grey area, with "communists" and "Ceaușescu", mixed with "endemic corruption", "attacks on justice and the rule of law", "political crisis", "political turmoil", "political drama", "the most volatile politics", "revolving-door governments", "nationalism", "scandal", and "chaos", especially when associated with the former PSD leaders, Liviu Dragnea and Viorica Dăncilă. The headlines of all the major international press institutions mentioned the change of governments, Euronews correspondents stating that there is "political horse-trading as parties jostle to form Romania's next government".

Another significant keyword in the international press was "diaspora", because the foreign journalists praised the "important rise of the Romanian diaspora vote" (Euronews). In fact, the Romanian diaspora played a key role also in the European elections, where the massive votes went to the PNL and USRPLUS political parties, affecting enormously the well-established PSD.

Other keywords were "migration", "poor infrastructure", "poor health care", "disparities between the urban centres and the villages", "economic growth", and "budget deficit", which reflect a complex, but also a problematic situation for Romania in years to come.

And, finally, for the fourth research question, What was the international media's perception of Romania in the context of the presidential elections?, we can say that the foreign press has high hopes for Romania's European future, because of the "huge victory" of Iohannis, the liberal government, and Romania's contribution to key institutions, such as the European Parliament, the European Commission, and the European Public Prosecutor's Office. But still, we shouldn't overlook the media's disappointment caused by the lack public debate between the presidential candidates. Unlike in the past, the presidential campaign for 2019 was "particularly subdued" and "it will be remembered as a non-campaign or, perhaps, it will not be remembered at all", as Romania was "preparing to choose its president in general silence" (Osservatorio Balcani e Caucaso Transeuropa).

\section{Conclusions}

The analysis of the reports in the media confirms the fact that there is a heavy political bias in Romania. The situation is not singular, as we can see that also in the USA the press is extremely biased. CNN is a TV channel that supports

61 Review of International Comparative Management

Volume 22, Issue 1, March 2021 
the democrats' political points of view, while Fox News supports the points of view in the republican area.

Another aspect is that we can observe a convergence of the European and American press when it comes to the two political forces involved in the presidential campaign: the right party, the PNL, was clearly appreciated in the news reports in comparison with the left party, represented by the PSD.

The big number of candidates (more than 10) didn't influence the media reports, which shows that without a strong party behind the presidential candidates, these independent candidates don't matter in the eyes of the electorate. The presidential elections from 2019 were the first presidential elections after December 1989 without direct meetings between the two candidates, not even on the Romanian Public Television, considered a neutral place. Candidate Iohannis thus imposed his communication strategy, relying on the fact that his opponent, Viorica Dăncilă, was permanently considered a candidate without political experience.

The migrant Romanians in the EU countries, generically named "diaspora", have massively voted the right-wing candidate. It can be said that they did it furiously, because the inefficiency and corruption of the PSD governments over time, after 1989, made them emigrate. No war in Romanian history led to such a massive departure from the country, of 5 million people, than what has happened after 1989.

The last conclusion, related to the European Parliament elections, is that no representative of the populist parties in Romania got in the European Parliament, which can be a signal that there is a solid attachment of the Romanians to the project of the European Union.

\section{References}

1. Magno, Francesco, "Presidential elections in Romania: wet powders", Osservatorio Balcani e Caucaso Transeuropa, 2019. Available at: https://www.balcanicaucaso.org/ eng/Areas/Romania/Presidential-elections-in-Romania-wet-powders-197735

2. Law no. 33/2007 on the organization and conduct of elections for the European Parliament

3. Decision no. 308 of March 26, 2019, on the rules for the audiovisual conduct of the electoral campaign, for the election of the Romanian members in the European Parliament. Available at: http://www.cna.ro/IMG/pdf/DECIZIE_nr._308_din_ 26_martie_2019_Alegeri_PE_2019.pdf

4. 2019 European election results. Romania - final results. Available at: https://europarl.europa.eu/election-results-2019/en/national-results/romania/2019-2024/

5. Decision no. 781 of March 3, 2019, on the rules for the audiovisual conduct of the 2019 presidential campaign. Available at: http://www.cna.ro/IMG/pdf/Decizie_nr._781_ din_03.09.2019_Alegeri_PRES_2019_CNA_.pdf

6. http://prezidentiale2019.bec.ro/ 


\section{Media sources}

ABC Internacional, ABC News, AFP, Al Jazeera, Associated Press, Balkan Insight, BBC, Bloomberg, Budapest Business Journal, Channel News Asia, Courrier des Balkans, Courrier International, CNBC, Deutsche Welle, Der Spiegel, Der Standard, El Confidencial, El Español, El País, El Periódico, El Territorio, Epoch Times, Euobserver, EurActiv, Euronews, France 24, Frankfurter Allgemeine Zeitung, Hungary Today, Irish Times, L'Express, La Croix, Le Figaro, Le Monde, Le Petit Journal, Le Soir, Le Temps, Les Echos, MDR, NBC, New York Times, One America News Network, Orange (France), Osservatorio Balcani e Caucaso Transeuropa, Ouest-France, Politico, Radio Free Europe, Reuters, RFI, RTL, RTVE, Sofia Globe, Star Tribune, Sud Presse, Süddeutsche Zeitung, Swiss Info, Telesur TV, Televisa, The Guardian, Tribune de Genève, TV5Monde, Voice of America, Washington Post, Washington Times, Xinhua, ZDF 